\title{
Cold Desert Fire and Invasive Species Management: Resources, Strategies, Tactics, and Response
}

\section{By Jeanne C. Chambers, Elizabeth Leger, and Erin Goergen}

"Land managers have to be both historians and visionaries so that they can identify the appropriate solutions." -workshop participant

\section{Cold Desert Regions}

he cold desert of North America, sometimes referred to as the Intermountain area, is comprised of a western Great Basin section and an L eastern Colorado Plateau section. In general, the cold desert receives more than half of its annual precipitation as snow, and because of its more northern latitude or higher elevations, has relatively low average annual temperatures. Snow cover is common and may last for weeks, yet summers can be hot. The Great Basin section is slightly cooler than the Colorado Plateau section and receives less summer precipitation. Droughts are common, especially in the Colorado Plateau section.

Major shrubland types in the cold desert occur over elevational gradients and exhibit distinct differences in site

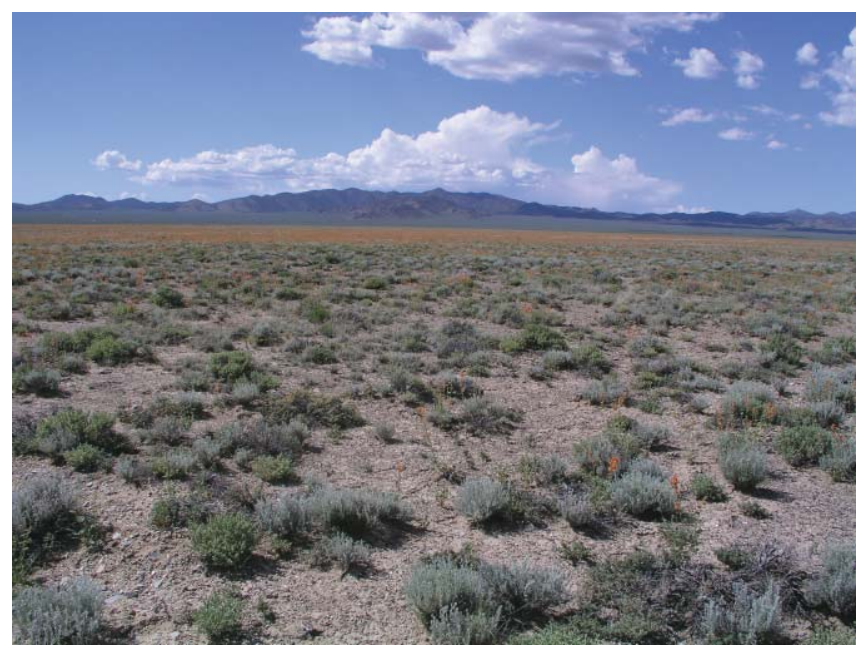

Salt-desert shrubland. productivity, fuel characteristics, and fire regimes. Saltdesert shrublands, which comprise about 30\% of the cold desert, typically occur at the lowest elevations, receive the least precipitation, and are dominated by species in the Chenopodiaceae like shadscale (Atriplex confertifolia). ${ }^{1}$ Sagebrush shrublands dominate the cold desert and occur over a range of elevations with Wyoming big sagebrush (Artemisia tridentata subsp. wyomingensis), black sagebrush (Artemisia nova), mountain big sagebrush (Artemisia tridentata subsp. vaseyana), and low sagebrush (Artemisia arbuscula) occurring at progressively higher elevations. ${ }^{2}$ Rabbitbrush (Chrysothamnus spp.) is locally prominent especially after disturbance. ${ }^{3}$ The Colorado Plateau has a high proportion of desert scrub characterized by shrubs like blackbrush (Coleogyne ramosissima). ${ }^{2}$ More summer precipitation in the Colorado Plateau allows more $\mathrm{C}_{4}$ (warm season) plants to thrive including grama grasses (Bouteloua spp.) and sand dropseed (Sporobolus cryptandrus). ${ }^{2}$ Because of limited summer precipitation in the Great Basin, $\mathrm{C}_{3}$ (cool season) plants including bluebunch wheatgrass (Pseudoroegneria spicata), Thurber's needlegrass (Achnatherum thurberianum), and Sandberg bluegrass (Poa secunda) dominate. ${ }^{2}$ Cool season grasses like Indian ricegrass (Achnatherum hymenoides) and needle-and-thread grass (Heterostipa comata) are abundant in both the Great Basin and Colorado Plateau. At mid-to-high elevations, both old-growth and expansion woodland trees often occur in association with sagebrush shrublands. Western juniper (Juniperus occidentalis), Utah juniper (Juniperus osteosperma), and singleleaf pinyon pine (Pinus monophyla) occur in the Great Basin. Utah juniper, one seed juniper (Juniperus monosperma), and two needle pinyon (Pinus edulis) are present in the Colorado Plateau. ${ }^{2}$

Historically, sagebrush-dominated shrublands had highly variable fire return intervals ranging from decades to centuries. ${ }^{4-6}$ At regional scales, fire return intervals in sagebrush shrublands were determined by climate and its effects on 


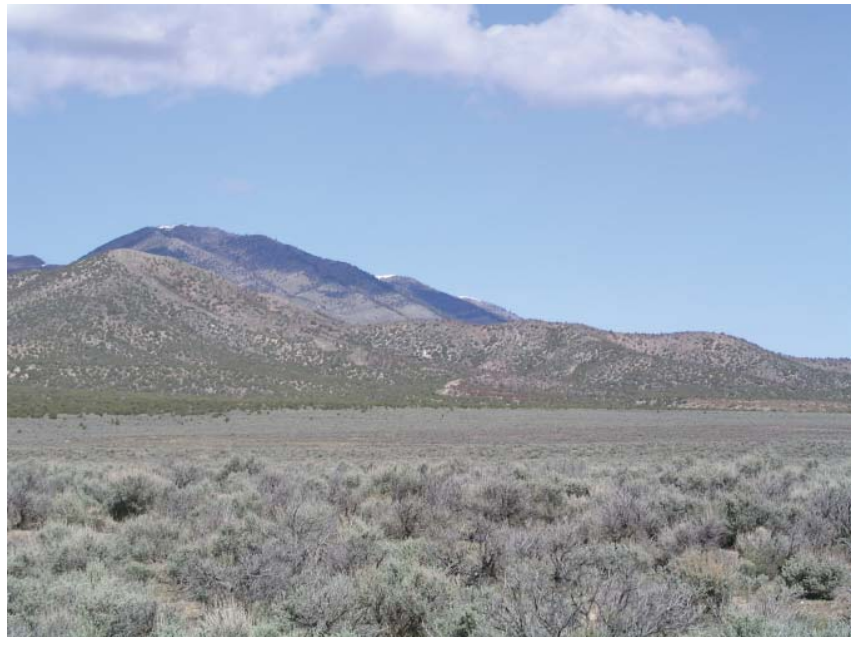

Sagebrush steppe and pinyon-juniper woodland.

fuel abundance and continuity. Consequently, fire frequency was higher in sagebrush types with greater productivity and during periods of increased precipitation., ${ }^{2,7}$ More locally within sagebrush types, fire return intervals in sagebrush shrublands were likely determined by topographic and soil effects on productivity and fuels, and were also highly variable. ${ }^{8}$ Salt-desert shrublands and desert scrub rarely if ever burned due to inherently low productivity and fuels loads. ${ }^{9}$

Before Anglo-Americans, Native Americans likely influenced vegetation through both intentional and accidental fires. ${ }^{10}$ Settlement of cold desert shrublands beginning in the mid-1800s initiated a series of changes in vegetation composition and structure that interacted with other global change processes to significantly alter fire regimes across the cold desert. Initially, inappropriate livestock use led to a decrease in native perennial grasses and forbs, and effectively reduced the abundance of fine fuels in the shrublands. ${ }^{11,12}$ Decreased competition from perennial herbaceous species in combination with ongoing climate change and favorable conditions for woody species establishment at the turn of century resulted in increased abundance of shrubs (primarily Artemisia species) and trees (J. occidentalis, J. osteosperma, J. monosperma, $P$. monophyla, $P$. edulis). The effect of these changes in fuel structure was a reduction in fire frequency and size. ${ }^{13}$ The next major change occurred when annual grasses (Bromus tectorum, Bromus madritensis subsp. rubens, Taeniatherum caput-medusa) were introduced from Eurasia in the late 1800s and rapidly spread into low- to mid-elevation shrublands with depleted understories. ${ }^{11}$ The annual grasses increased fine fuels and rate of fire spread in many shrubland communities and initiated grass-fire cycles characterized by shortened fire return intervals and larger, more contiguous fires. In recent decades, salt-desert shrublands began to burn for the first time in known history and Wyoming sagebrush types are burning as frequently as every few years., ${ }^{914}$ The final change occurred as a result of expansion of juniper and pinyon trees into mid- to high-elevation shrublands.
Progressive infilling of the trees is increasing woody fuels and causing fires of greater frequency, size, and intensity. ${ }^{13}$ The highly competitive trees are also resulting in depletion of species associated with sagebrush shrublands and reducing recovery potentials after fire.

Inappropriate livestock use, high intensity fires, and other factors that result in depletion of native perennial herbaceous species increase the susceptibility of cold desert shrublands to invasion by annual grasses following fire. Recent research indicates that for sagebrush shrublands within the ecological amplitude of cheatgrass, removal of perennial herbaceous species increases cheatgrass biomass and seed production two- to threefold. ${ }^{15}$ Fire alone results in a two- to sixfold increase in cheatgrass, but removal and fire combined can cause a ten- to thirtyfold increase. Most recently, secondary weeds like the knapweeds (Centaurea spp.), yellow star thistle (Centaurea solstitialis L.), and rush skeletonweed (Chondrilla juncea) are spreading through the region with poorly understood effects on fire regimes. ${ }^{16}$

\section{Challenges to be Faced}

The cold desert of western North America faces multiple challenges with regard to fire and invasive species management. Speakers at the Wildfire and Invasive Plants in American Deserts conference identified several critical management and research issues in cold deserts. Mr John Sullivan with the Boise Field Office of the Bureau of Land Management presented a case study of land management on the Snake River Birds of Prey National Conservation Area (NCA), located in southern Idaho. The NCA contains one of the most important nesting areas for birds of prey in North America, and land degradation and invasive species are affecting the abundance of the bird's primary food source-ground squirrels. Management on the NCA takes a targeted approach to restoration and fuels reduction, prioritizing areas that are most important to maintaining ground squirrel habitat rather than simply responding to

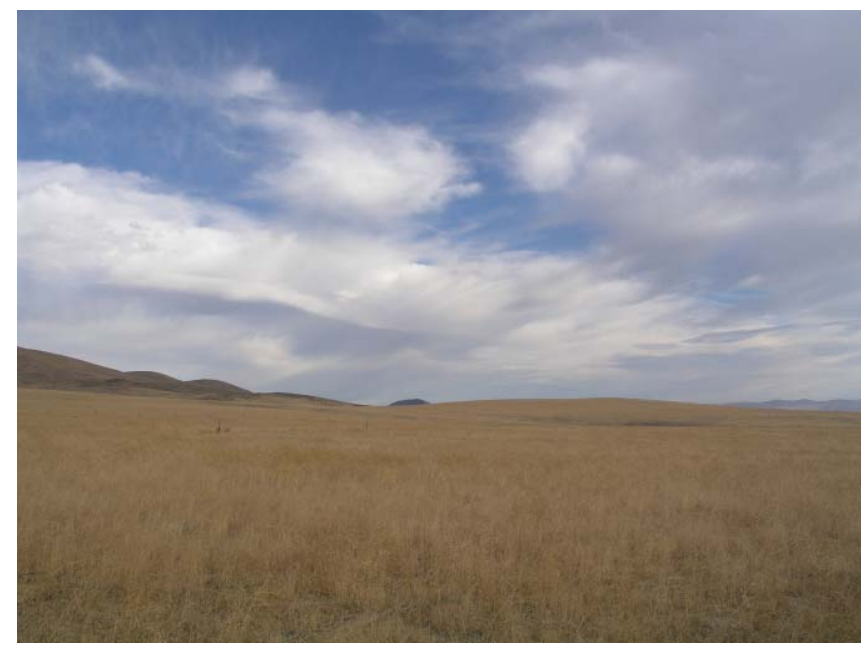

Sagebrush steppe converted to cheatgrass (Bromus tectorum). 
fires as they happen. Dr Roger Sheley with the Eastern Oregon Agricultural Research Center of the Agricultural Research Service emphasized the need to understand the causes of vegetation change that result in species invasions and altered fire regimes. He suggested that weed management should transition away from simply trying to control the symptom of invasion (the weeds) to managing the processes that result in invasion and weed dominance. Dr Steve Bunting with the Department of Rangeland Ecology and Management at the University of Idaho emphasized that vegetation changes after fire in western juniper woodlands are influenced by site characteristics and ecological resilience or recovery potential. The soil type, residual vegetation (seeds or plants), and ecological conditions including fuel loads all influence the post-fire vegetation. Given the right conditions, tree-dominated sites can transition into new and sometimes unexpected alternative states like annual grasslands dominated by cheatgrass or shrublands dominated by buckbrush (Ceonothus spp.). Dr Richard Miller with the Department of Rangeland Ecology and Management at Oregon State University suggested that management projects to maintain or restore sagebrush ecosystems exhibiting western juniper expansion need to focus on areas with low to moderate tree expansion rather than either old-growth woodlands or tree-dominated sites with little remaining understory vegetation. Dr Miller provided a set of questions that managers need to ask regarding soils, hydrology, and vegetation to determine the potential of a site to support a given ecological type and recover following treatments aimed at reducing tree cover and fuel loads. ${ }^{17}$

Workshop participants weighed in on what they felt were the most critical issues facing the cold desert (Fig. 1), and suggested solutions (Fig. 2). There was general agreement among workshop participants that the most critical issues to be addressed are invasion by annual grasses (notably cheatgrass) and the grass-fire cycle that can result. A related but less frequently mentioned issue was the

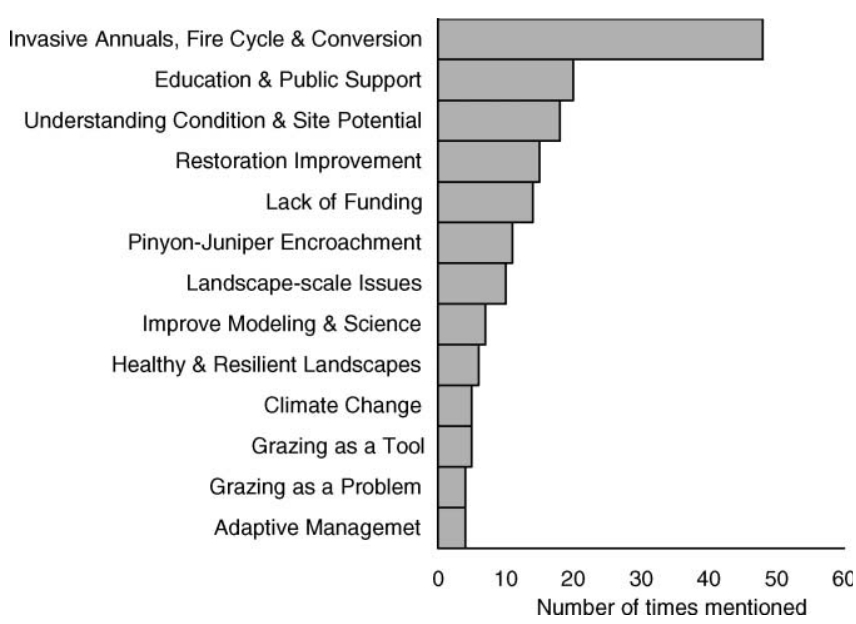

Figure 1. Summary of workshop participants' answers to the question "What are the critical issues facing cold deserts?"

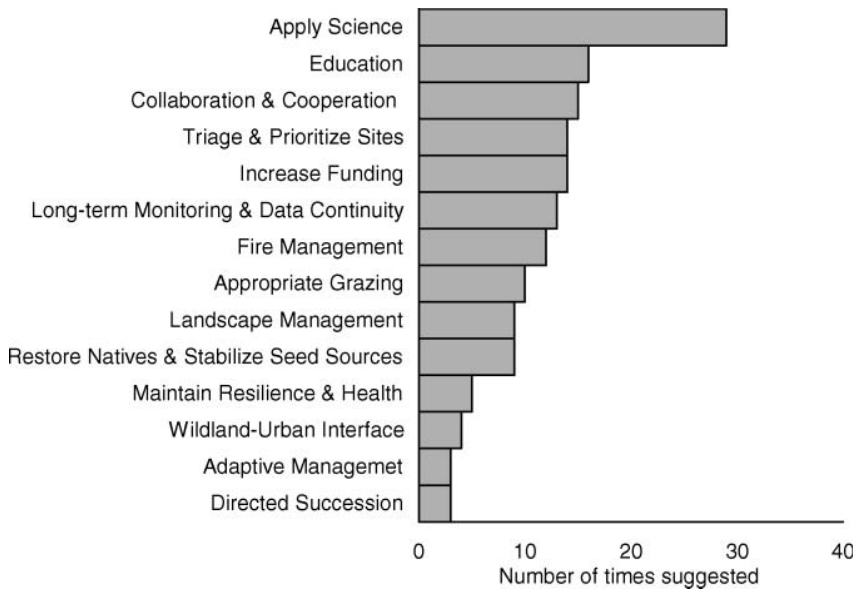

Figure 2. Summary of strategies workshop participants suggested for addressing issues facing the cold desert.

ongoing expansion of pinyon pine and juniper species $(P$. monophyla, P. edulis, J. occidentalis, J. osteosperma, J. monosperma) into sagebrush ecosystems, and the increasing potential for larger and more severe fires within the woodland zone. Importantly, the need to increase education regarding the threats to cold deserts as a way to obtain public support was the second most frequently mentioned issue, and the lack of funding for addressing critical issues was not far behind. A related concern was the need to increase science-based information applicable to the management of cold deserts. Many participants identified improving restoration and increasing our understanding of ecological condition and site recovery potential as important challenges in the cold desert. The need to clearly determine situations where grazing causes a nondesirable vegetation change versus those where grazing can be used as a potential tool in fire and invasive species management was mentioned by several participants. Managing for healthy and resilient landscapes was recognized as an important issue, as was addressing threats to cold desert ecosystems and performing restoration at landscape scales. Finally, increasing our understanding of the effects of climate change on fire and invasives was identified as a critical issue, as was the need for adaptive management in the face of ongoing change.

The strategies suggested by workshop participants for addressing the problems facing the cold desert reflected the critical issues (Fig. 2). The most frequent response given by workshop participants was that the best strategy for success in problem solving is to strengthen the linkages between science and management partners and to use science-based management approaches. Education about critical issues and the use of science-based management approaches, collaboration and cooperation among all partners, and increased funding were all suggested as important supporting strategies. A landscape-scale approach to management, the use of triage for prioritizing management activities, more effective use of fire management, and appropriate grazing management were all mentioned frequently. Long-term monitoring 
and data continuity were seen as critical for providing the necessary information for adaptive management. Restoration using directed succession ${ }^{18}$ and focusing on restoring natives was suggested by several individuals. Some participants mentioned the wildland-urban interface as a focal area. Others indicated that strategies for maintaining ecosystem resilience and health serve as the foundation for effective management of cold deserts.

In the following sections, we provide a synthesis of the specific strategies suggested by both the workshop presenters and participants.

\section{Science Recommendations Predicting Change}

The cold desert is an arid to semiarid region that is experiencing rapid population growth and is likely to be strongly affected by changes in climate that are predicted to occur over the next decades. ${ }^{19}$ Increasing the accuracy of predicted effects of climate change on cold desert ecosystems is critically important for effective management into the future. Equally important is increasing our ability to predict changes in vegetation communities and animal populations from invasion of annual grasses, expansion of pinyon and juniper woodlands, and altered fire regimes. It will be necessary to work across multiple disciplines-beyond natural systems to include sociology and economics- to determine the best management practices for cold deserts as human populations continue to expand. Predicting these changes will require greater use of both remote sensing and modeling.

\section{Addressing Important Needs and Critical Questions}

The probability that a given shrubland will transition to woodlands, to nonnative annual grasses, or both is linked to three ecological concepts: ecological resistance, ecological resilience, and thresholds. ${ }^{20}$ Ecological resistance is the degree to which a community maintains itself over time despite the introduction of invasive species. Ecological resilience describes the ability of a community to return to its predisturbance and, presumably, its pre-invasion state after a disturbance. Threshold crossings occur when a community does not return to the original state via natural processes following disturbance, but requires active management to restore the original state. ${ }^{21,22}$ Research and management projects aimed at understanding the factors that influence ecosystem resistance to invasive species and resilience after fire and other types of disturbance are needed both to prioritize areas for restoration and other management activities, and to develop effective treatments for different types of ecosystems. ${ }^{20}$ Defining the specific soil characteristics, vegetation composition, and abundance of different ecological types that are likely to result in recovery versus threshold crossings can be used to refine restoration and other management strategies. Further, increasing our

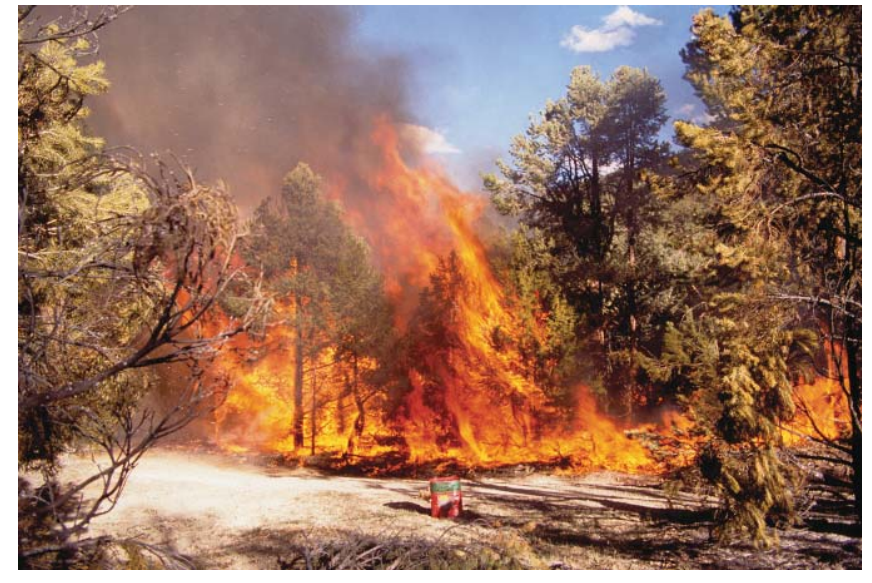

Use of prescribed fire in pinyon-juniper woodland.

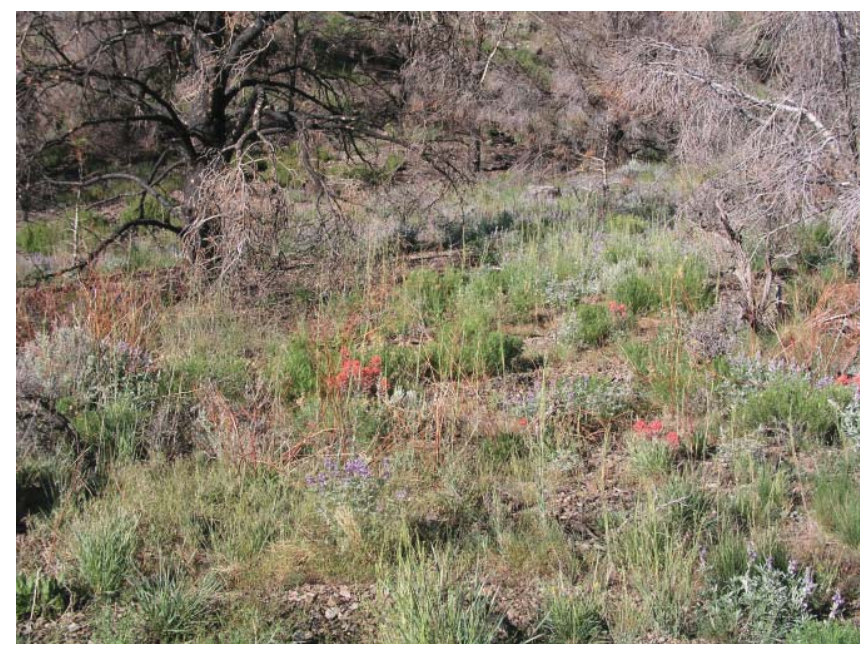

Recovery of sagebrush steppe following prescribed fire.

understanding of the effects of different management approaches, like biocontrol agents and prescribed or managed fire, is needed to effectively manage both wildfire and invasive species. For example, in pinyon-juniper ecosystems, it is necessary to identify methods for managing expansion that promote native recovery rather than conversion to an undesired state.

Restoration and rehabilitation activities are essential elements of managing for ecosystems that are resistant to invasive species and resilient to fire. The plant species used in restoration and rehabilitation efforts influence the success of the project, but have long-term effects on plant communities and the animals that depend on these communities. If disturbed sites are dominated by competitive annual grasses, like cheatgrass, native species may not establish. However, if disturbed sites have a reasonably high resilience or probability of recovering to native species, seeding introduced species can decrease the diversity of both plants and animals and result in introduced-species dominance. ${ }^{23}$ 
Research and management studies are needed to evaluate the short- and long-term effects of rehabilitation efforts focused on nonnative species like crested wheatgrass (Agropyron cristatum), forage kochia (Kochia prostrata), and brome (Bromus spp.) cultivars on both species diversity and ecosystem functioning. Introduced species may be effective for stabilizing soils on highly erosive sites and reducing cheatgrass on disturbed sites with a high risk of cheatgrass dominance. However, the trade-offs associated with planting introduced species may be too high in terms of decreased ecosystem functioning and species diversity on sites that are capable of recovering to native vegetation. Alternatives need to be considered for maintaining the resilience of these areas, such as vegetation treatments designed to increase the competitive ability of the perennial herbaceous component and creating green strips that can serve as firebreaks.

Major barriers to the use of native species in rehabilitation and restoration efforts are the lack of adequate seed sources and of effective methods for their establishment. Research and management projects are needed to identify promising native species, determine the environmental conditions and seeding methods under which they establish, and place them under cultivation for seed production. Promising new research indicates that native species may be adapting to the presence of cheatgrass by becoming more competitive. ${ }^{24}$ This strongly suggests that additional research is needed to determine if other native species are adapting to nonnative invaders as well as grazing and increased fire. If certain native species are exhibiting these adaptations, they are logical choices for inclusion in seed increase programs and restoration projects. Increasing the availability of native seed resources from the driest areas of the cold desert may also improve establishment.

Current land uses, like livestock grazing, can have significant effects on post-fire recovery and the outcomes of restoration and rehabilitation activities. The long-term effects of livestock grazing on species invasions and fire regimes in the cold desert are well understood. ${ }^{11,12,15}$ However, there is a lack of scientific information both on the use of grazing to control invasive species and on the effects of grazing on fire rehabilitation sites. Well-designed and carefully executed research and management experiments are needed to determine the effectiveness of grazing as a tool for controlling introduced annual grasses, the period of rest that is required under varying environmental conditions before reinstituting grazing after fire and rehabilitation or restoration treatments, and the timing and duration of grazing that is appropriate for burned and restored or rehabilitated areas.

\section{Developing New Concepts and Approaches}

Research and management activities aimed at addressing annual grass invasion and altered fire regimes need to look beyond individual sites and to begin addressing issues at landscape scales. Each management or treatment area is part of a larger, interconnected system, and modification or restoration of components at one scale can have effects at other levels. Research and management projects are needed that develop the necessary criteria and tools for devising management plans and projects that explicitly address landscape scales. An important element to consider when developing these criteria and tools is the relative resilience of the ecosystems that comprise landscapes and their likely responses to management actions. ${ }^{25}$ This requires understanding how landscape variables like patch sizes, degree of fragmentation, and corridors affect ecosystem functioning, community dynamics, and priority management species. It also requires understanding the resilience of the ecological types that comprise landscapes, and defining the abiotic and biotic thresholds that result in transitions to new states.

\section{Management and Policy Essentials and Changes}

Assessment and Monitoring

Routine assessment and monitoring provides the necessary information for adaptive management by tracking changes in ecological conditions over time and evaluating the results of management activities. In the cold desert, assessment and monitoring activities often differ both across and within agencies in terms of the specific data collected, methods used, length of time that measurements are collected, and analytical methods used to evaluate the monitoring data. Research and management organizations need to develop a collaborative network of sites that covers the major environmental gradients within the region to monitor ongoing change due to climate change, invasive species, altered fire regimes, and other large-scale environmental perturbations. Also, routine and consistent assessments of vegetation communities, ecological conditions, locations, and abundances of invasive species, and fire return intervals need to be conducted at management scales by all of the agencies. Monitoring and assessment data that are collected need to be placed in consistent databases that are readily accessible to all of the research and management organizations in the region. Coordination of data analysis, interpretation, and dissemination to management personnel would increase the impact of monitoring activities.

\section{Strategic Planning}

Ideally, management activities are prioritized based on management goals, routine assessments of current ecological conditions, and an understanding of the factors that influence resistance and resilience at both local and landscape scales. The most appropriate management strategy for areas of high resource value or at risk of crossing ecological thresholds is often protection from wildfires and other perturbations like overgrazing. These types of areas include remnant vegetation communities, old-growth pinyonjuniper woodlands, newly restored habitats, and areas of critical habitat. For areas that have moderate to high ecological resilience and have not crossed ecological thresholds, vegetation management can be used to maintain or increase 
resistance and resilience. This may involve reinstating fire, using herbicides, or implementing mechanical treatments to decrease woody vegetation and increase the competitive ability of native perennial herbaceous species. Active restoration and rehabilitation can be used to increase resistance and resilience of transitional or converted communities on post-fire areas and high-priority management areas like those adjacent to intact communities, at the wildland-urban interface, or that are critical habitat for threatened and endangered species.

\section{Education}

Educational tools and training regarding the threats to cold deserts and the potential management solutions are needed for both professional and lay audiences. For professionals, these include syntheses of existing knowledge, decision tools and guidelines for implementing effective invasive species and fire management, and decision tools and guidelines for restoration and rehabilitation treatments that consider resistance and resilience. For the public, these include materials written for the lay person on the issues facing cold deserts and the potential solutions. Websites, like those developed for the US Geological Survey National Biological Information Infrastructure, Great Basin Information Project (http:// greatbasin.nbii.gov), and the newly developed Great Basin Research and Management Project (http://greatbasin.wr. usgs.gov/GBRMP/index.html) can serve as clearing houses of information for both the lay person and the professional. They can also foster both communication and collaboration among the diverse group of organizations and individuals in the cold desert who share a common goal-sustaining cold desert ecosystems.

\section{Funding and Outreach}

The threats facing the cold desert can only be addressed through active communication and collaboration among the public, land mangers, policy makers, and researchers. Increased education about the threats to cold desert systems, and the practices appropriate for maintaining and restoring them, is needed to gain public support for management activities. Large-scale demonstration projects that involve the collaboration and cooperation of all interested parties like SageSTEP (www.sagestep.org) can be used to increase public support and funding for management and restoration goals and practices. Including all interested parties (managers, researchers, land owners, etc.) when evaluating sciencebased policy and developing management plans can help prevent future conflict. Protecting, managing, and restoring cold desert ecosystems is expensive and requires not only public support but also innovative, "out-of-the-box" funding solutions. Multi-organizational, multidisciplinary collaboration among the region's diverse organizations is essential for obtaining the funding to address the ecological and socioeconomic issues facing cold deserts. Effective partnerships will be inclusive in both the development and implementation stages, and will seek to leverage limited funds, increase efficiency, and avoid overlap.

\section{References}

1. West, N. E. 1983. Intermountain salt-desert shrubland. In: N. E. West [ED.]. Temperate deserts and semi-deserts. Amsterdam, The Netherlands: Elsevier Publishing Company. p. 375-398.

2. West, N. E. 1983. Great Basin-Colorado Plateau sagebrush semi-desert. In: N. E. West [ED.]. Temperate deserts and semideserts. Amsterdam, The Netherlands: Elsevier Publishing Company. p. 331-350.

3. West, N. E., And J. A. Young. 2000. Intermountain valleys and lower mountain slopes. In: M. B. Barbour and W. D. Billings [EDs.]. North American terrestrial vegetation. Cambridge, United Kingdom: Cambridge University Press. p. 256-284.

4. Frost, C. C. 1998. Presettlement fire frequency regimes of the United States. A first approximation. In: T. T. Pruden and L. A. Brennan [EDS.]. Fire in ecosystem management: shifting the paradigm from suppression to prescription. Proceedings of the 20th Tall Timbers Fire Ecology Conference. Tallahassee, FL, USA: Tall Timbers Research Station. p. 70-82.

5. Brown, J. K., And J. K. Sмith. 2000. Wildland fire in ecosystems: effects of fire on flora. Ogden, UT, USA: USDA Forest Service, Rocky Mountain Research Station, General Technical Report RMRS, GTR-42, volume 2. 257 p.

6. Baker, W. L. 2006. Fire and restoration of sagebrush ecosystems. Wildlife Society Bulletin 34:177-185.

7. Mensing, S., S. Livingston, and P. Barker. 2006. Long-term fire history in Great Basin sagebrush reconstructed from macroscopic charcoal in spring sediments, Newark Valley, Nevada. Western North American Naturalist 66:64-77.

8. Miller, R. F., and E. K. Heyerdahl. 2008. Fine-scale variation of historical fire regimes in sagebrush-steppe and juniper woodlands: an example from California, USA. International Journal of Wildland Fire 17:245-254.

9. Brooks, M. L., And D. A. Pyкe. 2001. Invasive plants and fire in the deserts of North America. In: K. E. M. Galley and T. P. Wilson [EDs.]. Proceedings of the invasive species workshop: the role of fire in the control and spread of invasive species. Fire Conference 2000. The First National Congress on Fire Ecology, Prevention, and Management; 27 November-1 December 2000; San Diego, CA, USA. Tallahassee, FL, USA: Miscellaneous Publication No. 11, Tall Timbers Research Station, USA. p. 1-14.

10. Kay, C. E. 2000. Native burning in western North America: implications for hardwood forest management. In: Proceedings: Workshop on Fire, People, and the Central Hardwoods Landscape, 12-14 March 2000; Richmond, KY, USA. Newtown Square, PA, USA: USDA Forest Service General Technical Report, NE-274. p. 19-27.

11. Knapp, P. A. 1996. Cheatgrass (Bromus tectorum L.) dominance in the Great Basin desert. Global Environmental Change 6:37-52.

12. Miller, R. F., and L. L. Eddleman. 2000. Spatial and temporal changes of sage grouse habitat in the sagebrush biome. Corvallis, OR, USA: Oregon State University. Agricultural Experiment Station Bulletin 151. 35 p. 
13. Miller, R. F., and R. J. Tausch. 2001. The role of fire in pinyon and juniper woodlands: a descriptive analysis. In: K. E. M. Galley and T. P. Wilson [EDs.] Proceedings of the invasive species workshop: the role of fire in the control and spread of invasive species. Fire Conference 2000. The First National Congress on Fire Ecology, Prevention, and Management; 27 November-1 December 2000; San Diego, CA, USA. Tallahassee, FL, USA: Miscellaneous Publication No. 11. p. 15-30.

14. Whisenant, S. G. 1990. Changing fire frequencies on Idaho's Snake River Plains: ecological and management implications. In: E. D. McArthur, E. M. Romney, S. D. Smith, and P. T. Tueller [comps.]. Proceedings-Symposium on Cheatgrass Invasion, Shrub Die-Off and Other Aspects of Shrub Biology and Management; 5 November 1989; Las Vegas, NV, USA. Ogden, UT, USA: USDA Forest Service, General Technical Report INT-276. p. 4-10.

15. Chambers, J. C., B. A. Roundy, R. R. Blank, S. E. Meyer, and A. Whittaker. 2007. What makes Great Basin sagebrush ecosystems invasible by Bromus tectorum? Ecological Monographs 77:117-145.

16. Kinter, C. L., N. L. Shaw, A. L. Hild, and B. A. Mealor. 2007. Post-fire seed ecology of rush skeletonweed (Chondrilla juncea L.): assessment of invasion potential. Rangeland Ecology and Management 60:386-394.

17. Miller, R. F., J. D. Bates, T. J. Svecar, F. B. Pierson, and L. E. Eddleman. 2007. Western juniper field guide: asking the right questions to select appropriate management actions. US Geological Survey Circular 1321. 61 p. Available at: http://pubs.usgs.gov/circ/1321. Accessed 26 June 2009.

18. Krueger-Mangold, J. M., R. L. Sheley, and T. J. Svecar. 2006. Toward ecologically-based invasive plant management on rangeland. Weed Science 54:567-605.
19. Chambers, J. C., and M. Pellant. 2008. Climate change impacts on Northwestern and Intermountain US rangelands. Rangelands 30(3):29-33.

20. D’Antonio, C. M., J. C. Chambers, R. Loh, and J. T. Tunison. (In press). Applying ecological concepts to the management of widespread grass invasions. In: R. L. Inderjit [ED.] Ecological invasions and restoration. Sunderland, MA, USA: Sinauer Associates.

21. Whisenant, S. G. 1999. Restoring damaged wildlands. A process-oriented, landscape scale approach. Cambridge, United Kingdom: Cambridge University Press. 312 p.

22. Briske, D. D., B. T. Bestelmeyer, T. K. Stringham, and P. L. Shaver. 2008. Recommendations for development of resilience based state-and-transition models. Rangeland Ecology and Management 61:359-367.

23. Lesica, P., and T. H. DeLuca. 1996. Long-term harmful effects of crested wheatgrass. Journal of Soil and Water Conservation 15:408-409.

24. Leger, E. A. 2008. The adaptive value of remnant native plants in invaded communities: an example from the Great Basin. Ecological Applications 18:1226-1235.

25. Wisdom, M. J., and J. C. Chambers. A landscape-scale approach for ecologically-based management of Great Basin shrublands. Restoration Ecology (in press).

Authors are Research Ecologist, USDA Forest Service, Rocky Mountain Research Station, Reno, NV 89512, USA, jchambers@fs.fed.us (Chambers); Assistant Professor (Leger), and Post-Doctoral Assistant (Goergen), Natural Resources and Environmental Sciences Dept, University of Nevada, Reno, NV 89512, USA. 